DOI https://doi.org/10.30525/978-9934-26-004-9-114

\title{
ДИЗАЙН ТА МИСТЕЦТВО: ІНТЕГРАЦІЯ ЧИ ПОГЛИНАННЯ
}

\author{
Семененко А. А. \\ кандидат філософських наук, \\ старший викладач кафедри культури \\ та соиіально-гуманітарних дисииплін
}

Національної академії образотворчого мистецттва і архітектури м. Київ, Україна

Процес розпаду „старих тотальностей”, вповні унаочнений нинішнім культурним досвідом, позбавив виміри людського світу сталих систем координат, дезорієнтував самоіндентифікації багатьох людських практик. Найбільш показовою, як завжди на будь-яких поворотних етапах, є доля мистецтва. Артефакти XX ст. побудовані на грі, самоіронії, відверто експлуатуючи мову комерції та споживання, являють профанацію та запозичення традиції; їх іронія та поверховість підриває усі серйозні метафізичні побудови. У постмодерністській свідомості знищено опозицію межу між раніш самостійними сферами духовної культури - між “науковою” та “буденною” свідомістю, "елітарною" та "масовою" культурою. Такий простір, плаский та ризомний є прозорим для всіх культурних практик, забезпечує їх інтеграцію та синтез. Водночас, всі вони рівною мірою стають бранцями нових станів культури - ситуацій кризи суб'єктивістських форм, кризи міжлюдської комунікації. Тепер мова формотворчих практик будь-якого рівня розвивається за рахунок широких пластів етно-специфікацій, традиційних форм та комерційного сленгу.

У просторі сучасної культури естетичне відношення реалізується переважно як резонатор таких людських відчуттів, як струс, шок, або як активатор інтелектуальної роботи реципієнта. Естетика „пост” передбачає не споглядання, а емоційну реакцію, не занурення, а дію, не сприйняття, а участь. Переосмислення нових реалій XX ст. наклало відбиток на розвиток естетичної науки, спрямувавши ії на дослідження проблем естетичного сприйняття, переживання, творчості, символу; до теоретичного арсеналу естетики були включені концепції артизації дійсності, ідеї багаторівневості та принципової незавершеності твору, „трансактивної парадигми” тощо. Проблема інтерпретації та проблема цінності висувається естетикою постмодерну як вихідна умова існування естетичного змісту. Самі реалії сучасного мистецького життя 176 
розширюють i, водночас, звужують межі художньої реальності, демонструючи новий виток проблематизації людського буття у світі.

Арсенал формотворчих засобів XX ст. великою мірою визначається експериментами авангарду з фактурою та структурою мистецьких творів. Нефігуративний живопис стає для дизайну справжнім джерелом нових форм виразності. Саме він, оголюючи сутнісну інтенцію всіх формовиявів - викликати почуття, спростовує традиційні алгоритми художнього впливу й відкриває горизонти безпосередніх контактів витвору 3 почуттєвою природою людини. В цьому сенсі сам нефігуративний живопис можна визнати провісником почуттєвого дизайну.

Сучасний дизайн активно використовує не тільки мову та засоби мистецьких практик, а й самі форми його реалізації. Так виникає артдизайн. 3 точки зору професійної діяльності, він проголошувався творчістю, звільненою від меркантильних інтересів, де у фокусі уваги образ, а метою є збудження, активізація, провокація емоцій та відчуттів. Неможливо строго визначити арсенал засобів, що застосовуються арт-дизайном, адже у дусі постмодерної реальності спростовані всі культурні ,табу”, сакральне й профане однаково впевнено залучаються до проектів будь-якого характеру та масштабу. Вироблені у таких вимірах дизайн-зразки мають вигляд моделей та композицій і створені за законами гри та фантазії.

Продовженням зазначеної тенденції змішування досвіду мистецтва та дизайну $\epsilon$ формування так званого „просторового стилю”, який передбачає театралізацію побуту, надання середовищу існування, помешканню - статусу сцени, театральної площини. Досліджуючи метаморфози сучасного мистецтва, В. Бичков визначає цю тенденцію як середовищний підхід $[1$, c. 519-520 ]. Сама людина (ii образ) проектується як інтегральна частина цього предметно-просторового середовища, як мобільна частка, що поєднує всі елементи цього простору. Подібні проектні задуми - розповсюджена стильова тенденція сучасного середовищно-просторового дизайну. У такому стилі дизайндіяльність набуває рис аранжування, а об'єктом проектування стає власне естетичний образ помешкання, а не самі речі. Цей образ життя, споживання завжди має своєю основою певні ідеологічні, мистецькі, філософські ідеї і прагне залучити споглядача у поле свого впливу.

Ще одним спільним полем застосування художньої та дизайнерської практики є стиль ,поп-дизайну”, безпосередньо включений у мистецький напрямок поп-арт. Використовуючи об'єкти щоденного споживання, соціальні фетиші та інші „банальні” цитати масової культури, цей стиль проголошує нову естетику, виразність та емоційність якої перевертає 
усталені критерії суспільного смаку. Засобами іронії, гротеску, провокації виробляється галерея спокусливих, життєрадісних, яскравих образів, що відверто проголошують невибагливість та безтурботність основою здорового світосприйняття. Втома від надмірної інтелектуалізації концептуального мистецтва та потреба у антидепресивних засобах для перевантаженої техногенними струсами сучасної людини складають підвалини поп-арту у всіх його проявах.

Тотальна тривіалізація всіх культурних практик трансформує їх сутнісні виміри та перетворює їх реальні втілення. Мислителі XX ст. визнали, що 80-ті роки пройшли під знаком легитимізації кічу, прийняття його елітарною культурою: тривіалізація „високого” мистецтва неминуча, бо в епоху підйому усіх видів репродукції справжній витвір мистецтва - анахронічний артефакт. Тенденції карнавалізації та гри протиставляють правильному Good Design-y, підпорядкованому єдиному та визначеному поняттю „доброго смаку”, безтурботність та оптимізм поп-дизайну з його інфантильно-іронічними формами, які апелюють до простих, безпосередніх емоцій та почуттів. Внутрішній зміст таких проектів - свято, карнавал, гра - окреслюють чинну тенденцію культури - необхідність компенсційних засобів для збереження природних людських почуттів та відчуттів в умовах зростаючого техногенного та соціального тиску. Театральність, еклектика та епатажність стають основними засобами естетичного впливу такого стилю, а кіч декларується як повноправний його чинник [2].

Ми спостерігаємо, як культура споживання диктує нові форми рефлексії. Мистецтво відмовляється від традиційних темпоральнопросторових меж: ready-mades та found objects, предметні компіляції та колажі, оп-арт, кінетична скульптура та живопис, заснований на хімічних реакціях, магнітних ефектах, злитий з фотографією та кіно - являють нову форму художнього, естетичного, засвідчують процеси синтезу та інтеграції різноманітних засобів виразності й відображають зближення та взаємопроникнення мистецького та дизайнерського досвіду. Актуалізація у сучасному дизайні питання розширення традиційних меж впливу - характерна ознака його сучасного розвитку, суголосна духу сучасного культурного моменту. „Речі купуються в результаті контакту" - усвідомлення цього факту маркетинговими структурами торговельних та виробничих фірм спрямовує інтерес та активність дизайнерів на урізноманітнення та вдосконалення цих контактів - від тактильних до складних асоціативних. В цьому сенсі дизайн-культура найнаочніше демонструє загальну тенденцію розвитку культури i естетики, що окреслюється поняттям „сінестезії” 
Сучасне формотворення засновано на співпраці вчених, інженерів, дизайнерів та митців й вибудовує нові предметні та віртуальні форми, відповідні запитам сучасності. Об'єкти архітектурно-дизайнерської та мистецької творчості сьогодні продовжують наукові дослідження й експерименти (біології, фізики, інформатики, кібернетики, досліджень штучного інтелекту, візуалізації інформації), втілюючи їх в аудіовізуальне технологічно- й/або електронно-сформоване середовище, доступне й для споглядання, а й для контактної взаємодії. Таке гібридне мистецтво виходить за межі жанровості, розмиваючи границі між живописом, скульптурою, інсталяцією, кіно, перфоменсом, й об'єднує науку, соціально-політичний контекст, поп-культурні пріоритети та синтезує всі можливі форми психо-емоційного впливу на людину, створюючи навколо нього психо-моторну систему масової комунікації 3 метою емоційно-тонізуючого або компенсаторно-реакреційного впливу. Тут з'являються нові напрямки: медійна архітектура, геопросторова розповідь, використання робототехніки та штучного життя.

\section{Література:}

1. Лексикон нонклассики. Художественно-эстетическая культура 20 в. / Под ред. В. В. Бычкова. М.: РОССПЭН, 2003. 608 с.

2. Пригорницька А. Дизайн: постмодерні формовияви. Українська академія мистецтва: дослідницькі та наук.-метод. Праці. - 2006. Вип. 13 - С. 211-219.

DOI https://doi.org/10.30525/978-9934-26-004-9-115

\section{КУЛЬТУРОЛОГІЧНИЙ ПІДХІД В ОСМИСЛЕННІ ДИЗАЙНУ}

\section{Сергеєва Н. В.}

кандидат мистецтвознавства, доцент, доиент кафедри дизайну

Черкаського державного технологічного університету м. Черкаси, Украӥна

Важко не погодитися, що останнім часом культурологічний підхід як напрям загальнонаукової методології набуває все більшого значення. Важливу роль він відіграв і в постановці проблематики дизайну в культурі, актуалізації дизайну як феномену культури. Це стало остаточно очевидним лише 3 другої половини XX-го століття і пов'язано з тим, що і 